\title{
SPATIAL-TEMPORAL OF FIRE FOCI IN THE STATE OF RIO DE JANEIRO, BRAZIL
}

\author{
ESPAÇO-TEMPORALIDADE DOS FOCOS DE CALOR NO ESTADO DO RIO DE \\ JANEIRO, BRASIL
}

\begin{abstract}
Givanildo de GOIS ${ }^{1}$; Welington Kiffer de FREITAS ${ }^{2}$; José Francisco de OLIVEIRA JÚNIOR ${ }^{3}$
1. Universidade Federal Fluminense, Pós-Doutorado do Programa de Pós-Graduação em Tecnologia Ambiental - PGTA, Volta Redonda, RJ, Brasil. givanildogois@gmail.com; 2. Universidade Federal Fluminense, Programa de Pós-Graduação em Tecnologia Ambiental - PGTA, Volta Redonda, RJ, Brasil. wkifferpgtauff@gmail.com; 3. Universidade Federal de Alagoas, Instituto de Ciências Atmosféricas - ICAT, Maceió, AL, Brasil. jose.junior@icat.ufal.br
\end{abstract}

\begin{abstract}
This study evaluated the space-time variability of fire foci via environmental satellites for the State of Rio de Janeiro (SRJ) based on statistical procedures. The fire foci in the period of 2000 to 2015 were obtained from the BDQueimadas fire database. Descriptive, exploratory, and multivariate statistical analyses were performed in the software environment $\mathrm{R}$ i386 version 3.2.5. The north region had 6760 foci $(21.11 \%)$, the south-central region had 3020 foci $(9.43 \%)$, the Middle Paraíba had 6,352 foci (19.84\%), the Metropolitan areas had 6671 foci (20.83\%), and the Green Coast region had 292 foci $(0.91 \%)$. The cluster analysis identified three homogeneous groups of fire foci $\left(\mathrm{G}_{1}, \mathrm{G}_{2}\right.$, and $\left.\mathrm{G}_{3}\right)$ but did not include the municipality of Campos dos Goytacazes $\left(\mathrm{N}_{\mathrm{A}}\right)$. The $\mathrm{G}_{1}$ group $(6.21 \pm 0.01$ foci, $57.61 \%)$ included areas throughout the state and covered the coastal region and lowlands towards the north. The $\mathrm{G}_{2}$ group $(6.21 \pm$ 0.01 foci, $34.81 \%)$ included the northern, south-central, and coastal shallows regions. The $G_{3}$ group $(6.21 \pm 0.01$ foci, $9.78 \%$ ) included the mountain ranges of the state. Environmental characteristics and socioeconomic are crucial in the dynamics of fire foci in Rio de Janeiro.
\end{abstract}

KEYWORDS: Wildfires. Burned. Environmental satellites. Statistical methods. Meteorological systems.

\section{INTRODUCTION}

In 1997, Brazil implemented an operational system called the Database of Fires (BDQueimadas), which was developed by the Center for Weather Forecasting and Climate Studies (CPTEC) of the National Institute for Space Research (INPE). The objective is monitoring the foci of fires and predicting the risk of fire in areas of vegetation (SETZER SISMANOGLU, 2006, CPTEC, 2016). BDQueimadas helps to prevent and minimize the environmental impacts caused by forest fires, especially in the Protected Areas in Brazil (CAÚLA et al. 2015; CLEMENTE; OLIVEIRA JÚNIOR; LOUZADA, 2017).

In the last decades, data from environmental satellites have been used to detect active fires and hot spots and to map burned areas (ROY; LEWIS; JUSTICE, 2002; CAÚLA et al., 2016). These data have been effective in monitoring, preventing, and combating fires (ROY et al., 2008; OLIVEIRA JÚNIOR et al., 2017). Based on the data, information and estimates of the location, period, and frequency of fires have been generated, which can provide evidence of their spatiotemporal dynamics (ANTUNES; RIBEIRO, 2000; SILVA; ROCHA; ANGELO, 2013). Systematic monitoring is essential for preventing and combating fires, especially in Protected Areas (FERNANDES et al.,
2011; NUNES et al., 2015), as well as in planning, control, and efficient management (BATISTA, 2003; PIROMAL et al., 2008).

With the technological advancement of orbital sensors and geotechnologies, it has become possible to determine how anthropogenic actions interfere with the environment and to help managers in making decisions in relation to large forest fires (BAILING JÚNIOR; MEYER; WELLS, 1992, COCHRANE, 2003, COCHRANE; BARBER, 2009). The most advanced orbital sensors are the Advanced-Very-High-Resolution Radiometer (AVHRR) (SETZER; VERSTRAETE, 1994; GITAS; MITRI; VENTURA, 2004) and the Moderate Resolution Imaging Spectroradiometer (MODIS) (HUETE et al., 2002, CORREIA et al., 2006; BOSCHETTI et al., 2008). MODIS provides data on phenomena occurring on the Earth's surface, in the oceans, and in the atmosphere (PIROMAL et al., 2008; CAÚLA et al., 2016).

Remote sensing (RS) products are used as tools for the detection of fire fire foci to understand the patterns of the ecosystem response to fire events (KEELEY; ZEDLER, 2009; CLEMENTE; OLIVEIRA JÚNIOR; LOUZADA, 2017). Fires produce changes in several types of ecosystems (SETZER; SISMANOGLU, 2006), such as increases in surface albedo, changes in carbon stocks, and decreases 
in the availability of water resources due to soil impact, erosion, and deposition processes of sediments in riverbeds (ANDERSEN et al., 2009; BROCK and CARPENTER, 2010). Furthermore, the transport of combustion products by smoke can spread materials that are potentially dangerous for human health (SILVA et al., 2012; SETZER; SISMANOGLU, 2006; CAÚLA et al., 2015). Several studies show that there are direct relationships between climate and forest fires, so the trends and distributions must be observed and considered in the development of management policies (BAILING JÚNIOR; MEYER; WELLS, 1992; BATISTA, 2003; NUNES et al., 2015; CAÚLA et al., 2015; CLEMENTE; OLIVEIRA JÚNIOR; LOUZADA, 2017).

Understanding the variability of fire foci in the State of Rio de Janeiro (SRJ) constitutes a fundamental strategy in the definition of public policies, especially in areas with high risk of fires in the Atlantic Forest biome (COURA et al.; 2010; FERNANDES et al.; 2011; CLEMENTE; OLIVEIRA JÚNIOR; LOUZADA, 2017; CLEMENTE; OLIVEIRA JÚNIOR; LOUZADA, 2017). However, there are few studies on fire foci in SRJ with a methodological approach involving statistical tools, geoprocessing, and RS products (CAÚLA et al., 2016) in the search for relational patterns of heat sources on the spatial and temporal scale. Therefore, the objective of this study was to evaluate the spatial-temporal variability of the fire foci via environmental satellites through BDQueimadas for the SRJ based on statistical procedures.

\section{MATERIAL AND METHODS}

\section{Study Area}

SRJ is located in the southeast region of Brazil between latitudes of $20^{\circ} 45^{\prime} 54$ and $23^{\circ} 21^{\prime} 57$ "S and longitudes of $40^{\circ} 57^{\prime} 59^{\prime \prime}$ and 44 53' 18 "W. It has an area of 43,696,054 $\mathrm{km}^{2}$ and borders Espírito Santo (ES) in the northeast (NE), Minas Gerais (MG) in the north and northwest (N-NW), São Paulo (SP) in the southwest, and the Atlantic Ocean to the south and east. It has an extensive coast that is approximately $635 \mathrm{~km}$ long. Currently, the Brazilian Institute of Geography and Statistics (IBGE) divides the geopolitical state into 92 municipalities (IBGE, 2018) and eight governmental regions (Metropolitan, Northern, Northwest, Coastal Flats, Mountainous, South-Central Fluminense, Middle Paraíba, and Green Coast), as shown in Figure 1.

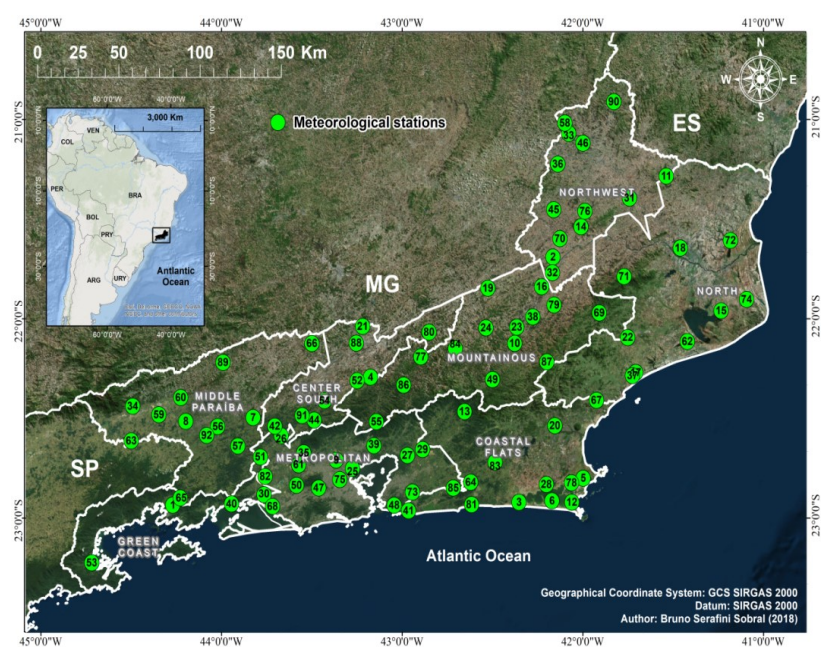

Figure 1. Location of meteorological stations in the State of Rio de Janeiro (Brazil) and subdivided in its eight regions of Government with 92 municipalities, respectively.

\section{Time series of fire foci}

Data on fire foci were obtained from BDQueimadas on the CPTEC website at the following

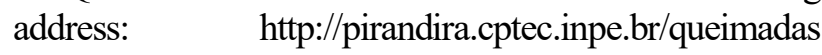
(CPTEC, 2016). Currently, CPTEC uses 31 environmental satellites with polar and geostationary orbits in its South American observation network. The environmental satellites include NOAA, GOES, AQUA (EOS PM-1), TERRA (EOS AM-1), METEOSAT, ATSR, and TRMM. These satellites perform orbital imaging in Brazil. The study period was from 2000 to 2015.

\section{Statistical analysis}

Analyses were done based on the following criteria: the application of descriptive statistics (DS) to describe and understand the series of fire foci in the SRJ; the measures of position (central tendency and separatrix) and dispersion (absolute and relative); and the annual accumulations of the fire foci subjected to an exploratory analysis (boxplot) with the purpose of 
identifying the major/minor occurrence periods of fire foci and outliers.

The annual cumulative time series of the fire foci obtained by the homogeneous groups from the cluster analysis (CA) were evaluated.

The CA technique was applied to the time series of fire foci in order to separate objects into groups based on the homogeneous characteristics that they have (EVERITT; DUNN, 1991; MONTGOMERY; RUNGER, 2007). The respective numbers of groups and a dendrogram of the 92 municipalities were determined based on the number of annual accumulated fire foci. The number of groups adopted and the stratification of fire foci were based on Ward's (1963) agglomerative hierarchical method by means of the measure of dissimilarity at the Euclidian distance (LYRA; OLIVEIRA-JÚNIOR; ZERI, 2014; BRITO et al., 2016). The Euclidean distance is given by equation 1 :

$\mathrm{d}_{\mathrm{E}}=\sqrt{\sum_{\mathrm{j}=1}^{\mathrm{p}}\left(\mathrm{x}_{\mathrm{ij}}-\mathrm{x}_{\mathrm{kj}}\right)^{2}}$

Where $d_{E}$ is the Euclidean distance, $x_{i j}$ are quantitative variables $\mathrm{j}$ of individuals $\mathrm{p}$, and $x_{k j}$ are quantitative variables $j$ of individuals.

In Ward's (1963) method, the distance between two clusters is the sum of the squares between the two clusters made for all variables. This method minimizes the dissimilarity or the total sum of squares within groups. That is, the data are grouped by homogeneity within each group and by heterogeneity outside each group (LYRA; OLIVEIRA-JÚNIOR; ZERI, 2014; BRITO et al., 2016).

$W=\sum_{\mathrm{i}=1}^{\mathrm{n}} \mathrm{xi}^{2}-\frac{1}{\mathrm{n}}\left(\sum \mathrm{xi}\right)^{2}$

$\mathrm{W}$ is the homogeneity and intragroup heterogeneity and is obtained by summing the square of the deviations, $n$ is the number of analyzed values, and $x_{i j}$ is the $i_{-t h}$ element of the cluster.

The standard deviation (SD) and the standard error (SE) of the annual fire foci were determined according to equations (3) and (4).

$\mathrm{SE}=\frac{D P}{\sqrt{n}}$
$\mathrm{SD}=\frac{\sqrt{\sum_{i=1}^{n}\left(x_{n}-\bar{x}\right)^{2}}}{n-1}$

Where is the $i_{\text {th }}$ observed fire focus, is the arithmetic mean of fire foci, and $\mathrm{n}$ is the sample size. All statistical procedures used in the study were calculated in the environment software R i386 version 3.4.2 R Core Team (2017).

\section{RESULTS AND DISCUSSION}

\section{Descriptive and exploratory statistics applied to the series of fire foci in the government regions of Rio de Janeiro}

The annual averages of fire foci increased significantly during the study period in SRJ. The highlight of 2015 is the average of 250 foci per government region. The North (6760 foci, 21.11\%), Metropolitan (6671 foci, 20.84\%), Middle Paraíba (6,352 foci, 19.84\%), and south-Central (3020 foci, $9.43 \%$ ) regions had the most fire foci. The high numbers in the respective regions are due to several factors, such as the quantity of factories, the complex relief (exposed granite), disorderly urban occupation, and the burning of waste and other associated human activities (mainly deforestation and agricultural activities) (CAÚLA et al., 2016; CLEMENTE; OLIVEIRA JÚNIOR; LOUZADA, 2017). There may also be temperatures above $47^{\circ} \mathrm{C}$ according to the orbital sensors of environmental satellites (SETZER; SISMANOGLU, 2006; CPTEC, 2016; CLEMENTE; OLIVEIRA JÚNIOR; LOUZADA, 2017).

There were 32,018 fire foci in SRJ, which had high temporal variability and the statistical parameters evaluated (Table 1). The Green Coast region had the lowest mean and SE (18 \pm 3.16 foci) compared to the northwest (129 \pm 4.86 foci) and Green Coast (127 \pm 32.95 foci). However, similar results were obtained for the SD of the regions. The minimum values obtained by region were 0 foci (Green Coast), 1 focus (Coastal Flats), 4 foci (Metropolitan), and 8 foci (Central South). In the north, northwest, Mountainous, and Middle Paraíba regions, there were $62,14,27$, and 25 foci, respectively.

The highest numbers were 41 foci in the Green Coast region, 486 foci in coastal shallows, 2,825 foci in Metropolitan areas, 939 foci in the south-Central region, 1,523 foci in the north region, 355 foci in the northwest region, 1,383 foci in Mountainous, and 1,345 foci in Middle Paraíba. The CV\% was lower in the Green Coast, northwest, north, and Middle Paraíba, in contrast to the Mountainous, coastal shallows, southern, and Metropolitan regions. 
The lower $\mathrm{CV} \%$ values indicate low variability of the fire foci between the regions. The high CV\% values represent significant changes in fire foci in SRJ during the study period (CLEMENTE; OLIVEIRA JÚNIOR; LOUZADA, 2017). The Ap coefficient characterizes how distant the data distribution is from a symmetric condition. The Ap coefficients for the eight SRJ regions showed a predominance of high asymmetric curves in the north (2.14), Mountainous (2.14), southCentral (2.20), and Metropolitan (2.47) regions, followed by (1.21), coastal shallows (1.59), and Middle Paraíba (1.18). However, the Green Coast region (0.22) presented a moderate positive asymmetry. In this case, the right tail is more elongated than the left tail for means greater than zero, which indicates the occurrence of high values with low frequency (VELÁSQUEZ et al., 2013, MACHIWAL; KUMAR; DAYAL, 2016). The K coefficients obtained for all regions of SRJ revealed leptokurtic distributions ( $\mathrm{K}>3$, sharpest curve) of annual heat accumulated foci for the north, Mountainous, south-Central, and Metropolitan regions, unlike the northwest regions, Middle Paraíba, Green Coast, and coastal shallows, which had platykurtic distributions ( $\mathrm{K}<3$, a more flattened curve) - (Table 1).

The North and Metropolitan regions had the highest annual amplitudes of 1,461 and 2,821 fire foci, respectively. The Mountainous and the Middle Paraíba regions had 1,356 and 1,345 foci, which were the lower and upper limits, respectively. The highest medians and SD occurred in the northern $\left(334.00 \pm 333.57\right.$ foci.years ${ }^{-}$ $\left.{ }^{1}\right)$, Metropolitan $\left(171.00 \pm 715.83\right.$ foci.years $\left.{ }^{-1}\right)$, Mountainous (197.50 \pm 329.04 foci.years $\left.^{-1}\right)$, and Middle Paraíba $\left(273.00 \pm 385.82\right.$ foci.years $\left.^{-1}\right)$.

Table 1. Results of the descriptive statistics applied to the time series of accumulated fire foci in the period of 2000-2015.

\begin{tabular}{|c|c|c|c|c|c|c|c|c|c|c|c|}
\hline \multirow[t]{2}{*}{$\begin{array}{c}\text { Governmental } \\
\text { Regions }\end{array}$} & \multirow{2}{*}{$\begin{array}{c}\text { Amount of } \\
\text { Fire Foci } \\
\left(\text { Foci. Year }{ }^{-1}\right) \\
\text { Accumulated } \\
\text { Annual } \\
\end{array}$} & \multirow{2}{*}{\multicolumn{2}{|c|}{$\begin{array}{c}(\%) \\
\text { Annual } \\
\text { Accumulat } \\
\text { ed Foci } \\
\text { Fire } \\
\end{array}$}} & Average & Medium & Mode & $\begin{array}{l}\text { Minimum } \\
\text { Value }\end{array}$ & $\begin{array}{l}\text { Maximum } \\
\text { Value }\end{array}$ & $\underset{\text { Total }}{\text { Amplitude }}$ & $\begin{array}{c}\text { Limit } \\
\text { Bottom }\end{array}$ & $\begin{array}{l}\text { Limit } \\
\text { Higher }\end{array}$ \\
\hline & & & & \multicolumn{8}{|c|}{$\left(\right.$ Focus. Year $\left.^{-1}\right)$} \\
\hline Northern & 6760 & \multicolumn{2}{|c|}{21.11} & 422.50 & 334.00 & 62.00 & 62 & 1523 & 1461 & 11.00 & 735.00 \\
\hline Northwest & 2062 & \multicolumn{2}{|c|}{6.44} & 128.88 & 99.50 & 14.00 & 14 & 355 & 341 & 66.63 & 290.38 \\
\hline Mountainous & 4827 & \multicolumn{2}{|c|}{15.08} & 301.69 & 197.50 & 27.00 & 27 & 1383 & 1356 & 252.75 & 739.25 \\
\hline South-Central & 3020 & \multicolumn{2}{|c|}{9.43} & 188.75 & 133.00 & 8.00 & 8 & 939 & 931 & 235.63 & 529.38 \\
\hline Coastal Flats & 2034 & \multicolumn{2}{|c|}{6.35} & 127.13 & 84.50 & 99.00 & 1 & 486 & 485 & 104.13 & 302.88 \\
\hline Metropolitan & 6671 & \multicolumn{2}{|c|}{20.84} & 416.94 & 171.00 & 4.00 & 4 & 2825 & 2821 & 209.00 & 655.00 \\
\hline Middle Paraíba & 6352 & \multicolumn{2}{|c|}{19.84} & 397.00 & 273.00 & 25.00 & 25 & 1345 & 1320 & 416.13 & 1016.88 \\
\hline Green Coast & 292 & \multicolumn{2}{|c|}{0.91} & 18.25 & 17.00 & 17.00 & 0 & 41 & 41 & 17.25 & 50.75 \\
\hline Total & 32018 & \multicolumn{2}{|c|}{100} & 2001.13 & 1309.50 & 256.00 & \multirow{2}{*}{$\begin{array}{l}\text { Standard } \\
\text { deviation } \\
\text { (SD) }\end{array}$} & \multirow{2}{*}{$\begin{array}{c}\text { Standar } \\
\text { d error } \\
\text { (SE) }\end{array}$} & \multicolumn{2}{|c|}{ Quartile } & Interqua \\
\hline \multirow{2}{*}{$\begin{array}{l}\text { Governmental } \\
\text { Regions }\end{array}$} & \multicolumn{6}{|c|}{ Coefficients } & & & $\begin{array}{c}\text { Bottom } \\
\left(Q_{1}\right)\end{array}$ & $\begin{array}{l}\text { Higher } \\
\left(Q_{3}\right)\end{array}$ & $\begin{array}{c}\text { rtile } \\
\text { Range } \\
\text { (AIQ) }\end{array}$ \\
\hline & $\begin{array}{l}\text { Sampling } \\
\text { Variation } \\
\text { (\%) (CV) } \\
\end{array}$ & \multicolumn{2}{|c|}{$\begin{array}{c}\text { Asymmetry } \\
\left(A_{p}\right)\end{array}$} & \multicolumn{3}{|c|}{$\begin{array}{c}\text { Curtose } \\
\text { (K) }\end{array}$} & \multicolumn{5}{|c|}{ (Focus. Year ${ }^{-1}$ ) } \\
\hline Northern & 78.95 & 2.14 & + & 4.57 & \multicolumn{2}{|c|}{ leptokurtic } & 333.57 & 83.39 & 268.75 & 455.25 & 186.50 \\
\hline Northwest & 77.15 & 1.21 & + & 0.45 & \multicolumn{2}{|c|}{ platykurtic } & 99.43 & 24.86 & 67.25 & 156.50 & 89.25 \\
\hline Mountainous & 109.07 & 2.14 & + & 4.41 & \multicolumn{2}{|c|}{ leptokurtic } & 329.04 & 82.26 & 119.25 & 367.25 & 248.00 \\
\hline South-Central & 120.33 & 2.20 & + & 4.58 & \multicolumn{2}{|c|}{ leptokurtic } & 227.13 & 56.78 & 51.25 & 242.50 & 191.25 \\
\hline Coastal Flats & 103.66 & 1.59 & + & 1.47 & \multicolumn{2}{|c|}{ platykurtic } & 131.78 & 32.95 & 48.50 & 150.25 & 101.75 \\
\hline Metropolitan & 171.69 & 2.47 & + & 5.22 & \multicolumn{2}{|c|}{ leptokurtic } & 715.83 & 178.96 & 115.00 & 331.00 & 216.00 \\
\hline Middle Paraíba & 97.21 & 1.18 & + & 0.24 & \multicolumn{2}{|c|}{ platykurtic } & 385.92 & 96.48 & 121.25 & 479.50 & 358.25 \\
\hline Green Coast & 69.21 & 0.22 & + & -1.18 & \multicolumn{2}{|c|}{ platykurtic } & 12.63 & 3.16 & 8.25 & 25.25 & 17.00 \\
\hline
\end{tabular}

This showed that the annual accumulated heat outlets in all SRJ regions had an asymmetric distribution. $25 \%$ of accumulated fire foci occurred below the median in the north, northwest, Mountainous, south-Central, coastal shallows, Metropolitan, and Middle Paraíba regions. The value of the first quartile (Q1) ranged from 48.50 to 268.75 foci.year ${ }^{-1}$ and was greater than $25 \%$ of the values of the third quartile $(\mathrm{Q} 3)$, which ranged from
150.25 to 455.25 foci.year ${ }^{-1}$. The interquartile range (AIQ) ranged from 89.15 to 358.25 foci.year $^{-1}$ in the respective regions. The exception was the Green Coast region, which presented the lowest median, and $25 \%$ of the accumulated fire foci were lower than Q1 and or higher than Q3 (between 8.25 and 25.25 foci.year $^{-1}$ ). The AIQ was 17.00 foci.year $^{-1}$. 
Spatial-temporal...

The analysis of the sample CV\% for the SRJ government regions showed that the majority of the regions presented values above $70 \%$. This indicated high temporal variability of annual heat accumulated in the SRJ. The higher SD and higher AIQs indicated a high degree of variability of annual accumulated fire foci around the average in the north, northwest, Mountainous, south-Central, coastal bays, Metropolitan, and Middle Paraíba regions (Table 1). The temporal variability in the detection of fire foci in SRJ can be explained by the anthropic actions along with the development of orbital sensors (AVHRR and MODIS) and algorithms, such as the Wild Fire-Automated Biomass Burning Algorithm (WF-ABBA) number (currently 31) and the types of satellites (polar or geostationary orbit), which are crucial factors in the increase in foci. INPE used the NOAA-12 reference satellite until August 2007 and then adopted the NOAA15 satellite. Currently, it uses the AQUA-MT and TERRA-MT satellites (CPTEC, 2016).

According to Caúla et al. (2015), the AQUAMT satellite has a polar orbit, and it is more successful in detecting fire foci per unit area in Brazil compared to geostationary satellites and in relation to others with the same orbit, such as the old reference satellites mentioned. The influence of meteorological systems on the time series of fire foci in SRJ, which in turn influence rainfall patterns and the distribution of temperature and
GOIS, G. et al.

humidity in the air, is also not ruled out. In this paper, we present the results of a study of forest fires and general fires (BATISTA, 2003; NUNES et al., 2015, OLIVEIRA JÚNIOR et al., 2017)..

\section{Homogeneous regions of fire foci}

The CA technique identified three homogeneous groups of fire foci $\left(\mathrm{G}_{1}, \mathrm{G}_{2}\right.$, and $\left.\mathrm{G}_{3}\right)$ and only the municipality of Campos dos Goytacazes did not cluster $\left(\mathrm{N}_{\mathrm{A}}\right)$. Campos dos Goytacazes had more fire foci and was an outlier in the time series. The CA technique grouped all municipalities independently of the government region (Figure 2). The highest number of hot spots in Campos dos Goytacazes was due to the large areas of pasture, climatic conditions (high temperature and low rainfall) (BRITO et al., 2016, SOBRAL et al., 2018), and the production and harvest of sugarcane based on the practice and common use of fires (CAÚLA et al., 2016; CLEMENTE; OLIVEIRA JÚNIOR; LOUZADA, 2017). Furthermore, there is a greater number of industries in the region (IBGE, 2018). The results corroborate those from FERNANDES et al. (2011), who classified SRJ into regions of fire susceptibility. The North Fluminense was classified as a region of high susceptibility due to the factors mentioned and slopes with a high incidence of solar radiation.

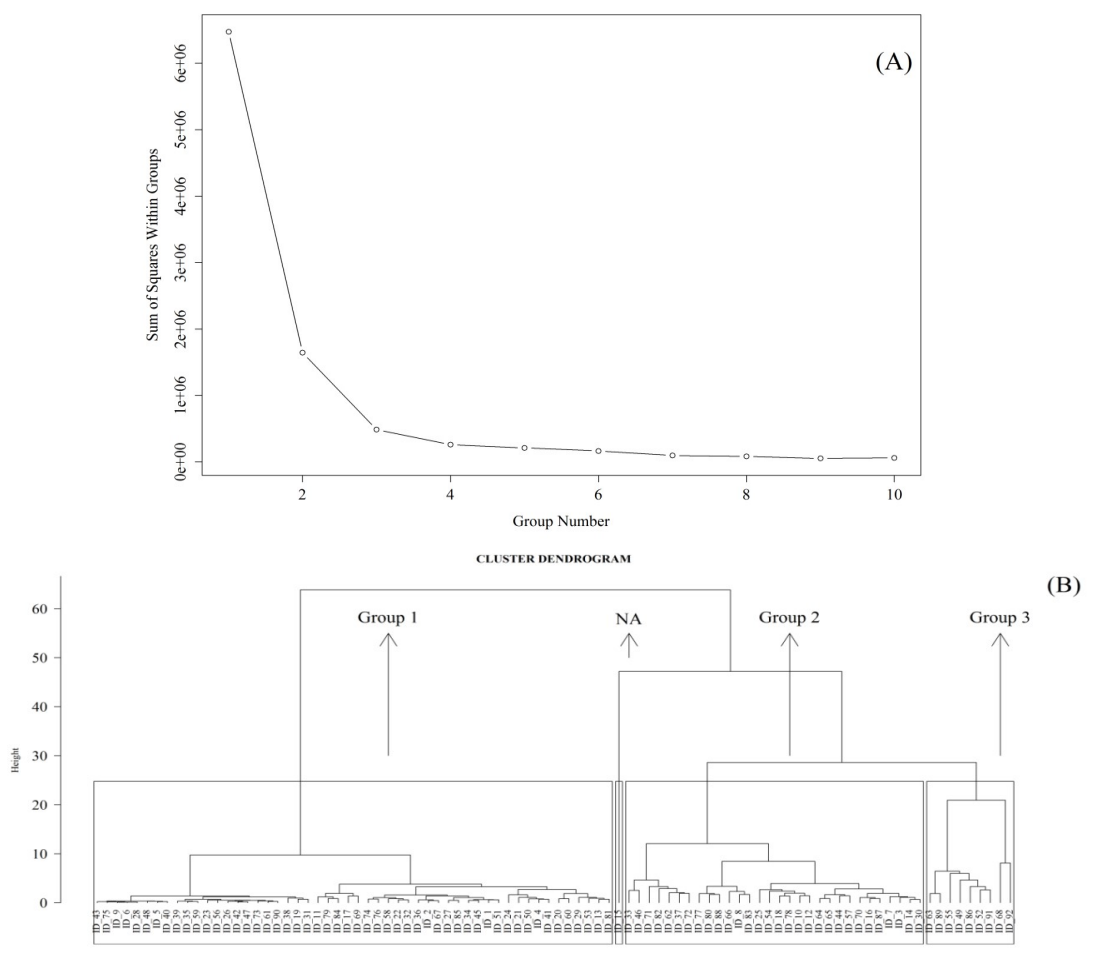

Figure 2. Group Number (A) and Dendrogram (B) obtained from the cluster analysis of the fire foci of the municipalities of the State of Rio de Janeiro, with their respective homogeneous groups $\left(\mathrm{G}_{1}, \mathrm{G}_{2}, \mathrm{G}_{3}\right.$ and $\left.\mathrm{N}_{\mathrm{A}}\right)$. 
The exploratory analysis technique was applied for $\mathrm{G}_{1}, \mathrm{G}_{2}$ and $\mathrm{G}_{3}$ via boxplot (Figure 3), using the mean values of the statistical parameters (mean, median, maximum, minimum and $1^{\text {st }}$ and $3^{\text {rd }}$ quartile) of the fire foci. The $\mathrm{G}_{1}$ group was represented by Figure 3 (a), being the largest homogeneous group of fire foci, consisting of 53 municipalities in the state (57.61\%). In group $\mathrm{G}_{1}$, outliers were registered for all years of the dataset, the exceptions were 2003, 2005 and 2010. The highlights were 2014 and 2015, which registered most number of outliers, followed by average values $(20.46$ and 18.85 focus) greater than the median (14.00 and 12.50 focus). Similar to group $G_{1}$, outliers were also observed in group $G_{2}$, again there were exceptions for
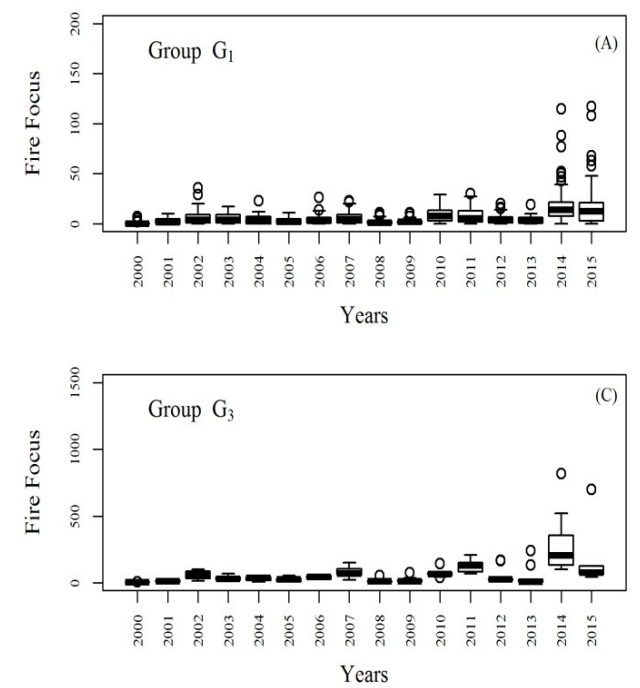

the years 2000, 2003 and 2007. Group $\mathrm{G}_{2}$ was the second largest group consisting of 30 municipalities (34.81\%), with an average ranging from 81.43 to 66.00 and the medians from 49.07 to 35.50 , and an SD of 27.89 fire foci. In group $\mathrm{G}_{3}$, there was a significant reduction of outliers. Group $\mathrm{G}_{3}$ was the smallest homogeneous group consisting of nine municipalities (9.78\%), ranging between 314.13 and 361.33 foci and with a median of 204.50 and 76.00 foci and the largest SD (196.75) compared to the other homogeneous groups. $\mathrm{N}_{\mathrm{A}}$ did not show any outliers in the time series although 2015 registered 1000 fire focus.
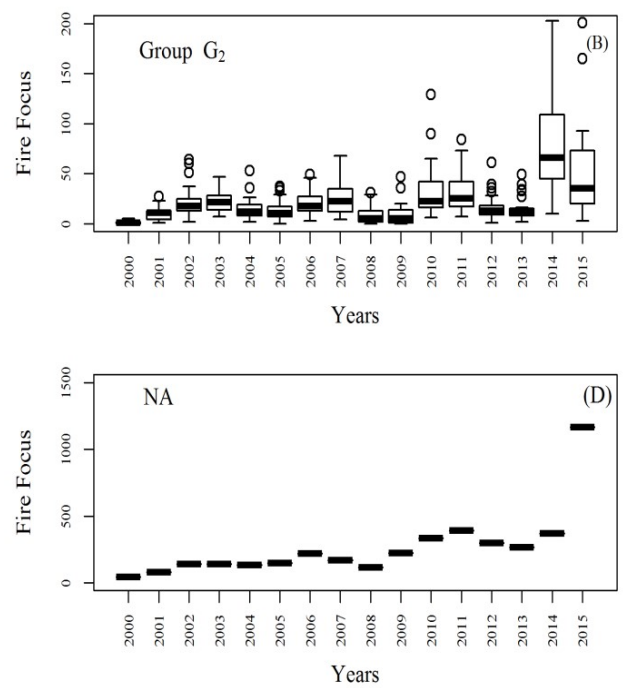

Figure 3. Boxplot of homogeneous groups $\mathrm{G}_{1}(\mathrm{~A}), \mathrm{G}_{2}(\mathrm{~B}), \mathrm{G}_{3}(\mathrm{C})$ and $\mathrm{NA}(\mathrm{D})$ of hot flashes from 2000 to 2015 in the state of Rio de Janeiro.

The $\mathrm{G}_{1}$ group covered the coast and the Coastal Flats region towards the northern part of the state. The southern part extends from the northeast to southwest. The $\mathrm{G}_{2}$ group had a similar distribution to group $\mathrm{G}_{1}$. The highest concentrations of municipalities were observed in the north $(55.56 \%)$, Coastal Flats $(45.45 \%)$, and Middle Paraíba (41.67\%) with five municipalities each (Figure 4 ande Table 3).

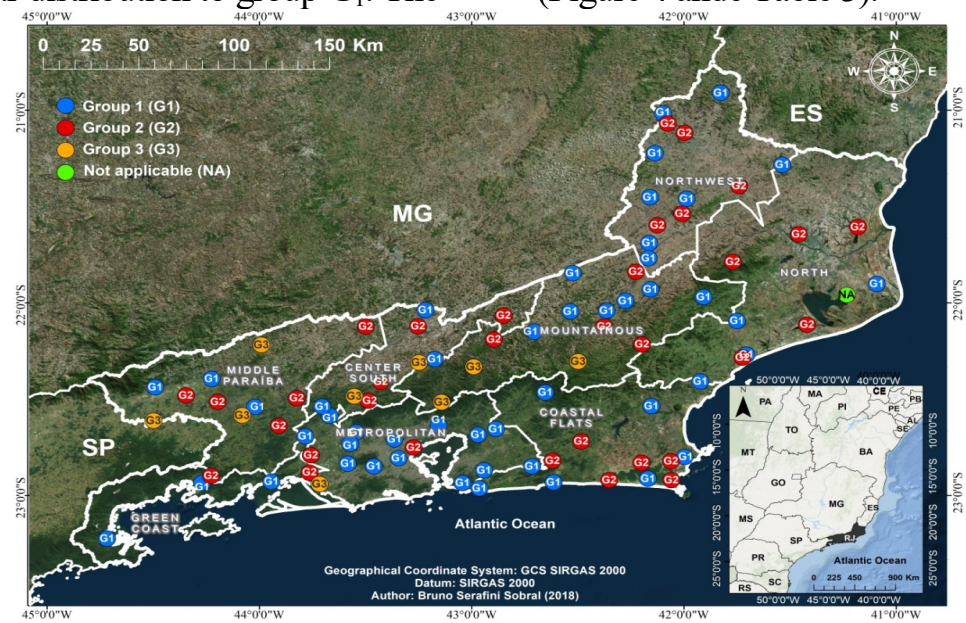

Figure 4. Spatial distribution of the homogeneous groups of fire foci $\mathrm{G}_{1}, \mathrm{G}_{2}, \mathrm{G}_{3}$ and $\mathrm{N}_{\mathrm{A}}$ in the State of Rio de Janeiro in the period 2000-2015. 
Table 3. Percentage (\%) of fire foci by government region and homogeneous groups $\left(G_{1}, G_{2}, G_{3}\right.$ and $\left.N_{A}\right)$ in the period of 2000-2015 in the State of Rio de Janeiro.

\begin{tabular}{llllllllll}
\hline $\begin{array}{l}\text { Governmental } \\
\text { Regions }\end{array}$ & $\mathbf{G}_{\mathbf{1}}$ & $\begin{array}{l}\mathbf{( \% )} \\
\text { Governmental } \\
\text { Regions }\end{array}$ & $\begin{array}{l}\mathbf{( \% )} \\
\text { Group }\end{array}$ & $\mathbf{G}_{\mathbf{2}}$ & $\begin{array}{l}\mathbf{( \% )} \\
\text { Governmental } \\
\text { Regions }\end{array}$ & $\begin{array}{l}(\%) \\
\text { Group }\end{array}$ & $\mathbf{G}_{\mathbf{3}}$ & $\begin{array}{l}\text { (\%) } \\
\text { Governmental } \\
\text { Regions }\end{array}$ & $\begin{array}{l}\text { (\%) } \\
\text { Group }\end{array}$ \\
\hline Northern & 3 & 33.33 & $6 \%$ & 5 & 55.56 & $17 \%$ & 0 & 0.00 & $0 \%$ \\
Northwest & 9 & 69.23 & $17 \%$ & 4 & 30.77 & $13 \%$ & 0 & 0.00 & $0 \%$ \\
Mountainous & 8 & 53.33 & $15 \%$ & 4 & 26.67 & $13 \%$ & 3 & 20 & $33 \%$ \\
South-Central & 4 & 44.44 & $8 \%$ & 4 & 44.44 & $13 \%$ & 1 & 11.11 & $11 \%$ \\
Coastal Flats & 6 & 60 & $12 \%$ & 4 & 40.00 & $13 \%$ & 0 & 0 & $0 \%$ \\
Metropolitan & 15 & 75 & $29 \%$ & 4 & 20.00 & $13 \%$ & 1 & 5 & $11 \%$ \\
Middle Paraíba & 4 & 30.77 & $8 \%$ & 5 & 38.46 & $17 \%$ & 4 & 30.77 & $44 \%$ \\
$\begin{array}{l}\text { Green Coast } \\
\text { TOTAL }\end{array}$ & 3 & 100 & $6 \%$ & 0 & 0.00 & $0 \%$ & 0 & 0 & $0 \%$ \\
\hline
\end{tabular}

The $\mathrm{G}_{3}$ group had a smaller number of municipalities in the Middle Paraíba (30.77\%) and the Mountainous region (20.00\%). The entire $\mathrm{G}_{3}$ group was concentrated along the mountain ranges of SRJ from Serra do Mar, which is part of Serra dos Órgãos in the Mountainous region, up to the Serra da Mantiqueira. The southewest border is shared with the States of São Paulo and Minas Gerais, where the rest of the Atlantic Forest is located. The differences in the numbers of fire foci are mainly due to local characteristics, such as vegetation, proximity to the coastal environment, complex topography, and multiscale meteorological systems that affect the region's climate (CAÚLA et al. 2016, FERNANDES et al., 2011; NUNES et al., 2015). Human activities also contribute to the variation (FERNANDES et al., 2011).

\section{CONCLUSIONS}

The statistical analysis has shown that the north, south-Central, Middle Paraíba, and Metropolitan regions stand out in relation to the temporal variability of fire foci in SRJ, but not the Green Coast region. The applied statistics clearly show that there is a considerable increase of fire foci in Rio de Janeiro throughout the time series, with emphasis on the high spatial-temporal variability in the government regions. The number of foci significantly increased in the analysis period due to the anthropic actions of each government region, the development of orbital sensors, and the increase of the numbers and types of environmental satellites.

Three homogeneous groups of fire foci were identified based on cluster analysis $\left(\mathrm{G}_{1}, \mathrm{G}_{2}\right.$ and $\left.\mathrm{G}_{3}\right)$, together with the municipality of Campos dos Goytacazes $\left(\mathrm{N}_{\mathrm{A}}\right)$. This was achieved using Ward's method with the Euclidian distance as a dissimilarity measure. Spatially, the $G_{1}$ group was the largest in terms of the number of municipalities, which were spread throughout SRJ and covered the coastal and lowland regions towards the north. The $\mathrm{G}_{2}$ group had a similar distribution to $\mathrm{G}_{1}$ but with predominance in the north, south-central, and coastal shallows regions. The $\mathrm{G}_{3}$ group was concentrated along the mountain ranges of the state. The local characteristics, proximity to the coast, complex topography, and multiscale meteorological systems contribute to the fire risk and are crucial factors in the spatio-temporal variability of fire foci in the state.

\section{ACKNOWLEDGMENTS}

To Coordenação de Aperfeiçoamento de Pessoal de Nível Superior - CAPES - for the PNPD scholarship, to the Postgraduate Program in Environmental Technology - PGTA of the Universidade Federal Fluminense.

RESUMO: Este estudo avaliou a variabilidade espaço-temporal de focos de calor via satélites ambientais para o Estado do Rio de Janeiro (SRJ) com base em procedimentos estatísticos. Os focos de calor no período de 2000 a 2015 foram obtidos a partir do banco de dados de focos do BDQueimadas. Análises estatísticas descritivas, exploratórias e multivariadas foram realizadas no ambiente de software R i386 versão 3.2.5. A região Norte tinha 6760 focos $(21,11 \%)$, a região Centro-Sul tinha 3020 focos (9,43\%), o Médio Paraíba tinha 6,352 focos $(19,84 \%)$, as áreas metropolitanas tinham 6671 focos $(20,83 \%)$ e a Costa Verde região teve 292 focos $(0,91 \%)$. A análise de agrupamento identificou três grupos homogêneos de focos de calor $\left(\mathrm{G}_{1}, \mathrm{G}_{2} \mathrm{e} \mathrm{G}_{3}\right)$, mas não incluiu o município de Campos dos Goytacazes $\left(\mathrm{N}_{\mathrm{A}}\right)$. Em que se observa no grupo $G_{1}$ uma forte presença de outliers com valores atípicos, em todos os anos da série temporal, sendo destaque para os anos de 2014 e 2015 que apresentam os maiores números de outliers seguidos dos valores das 
médias (20.46 e 18.85 focos) acima das medianas (14.00 e 12.50 focos). Comportamentos semelhantes foram observados nos grupos $\mathrm{G}_{2}$ e $\mathrm{G}_{3}$, sendo o grupo $\mathrm{G}_{2}$ com média (81.43 $\mathrm{mm}$ e 66.00 focos) e medianas (49.07 e 35.50 focos) com um DP de 27.89 focos de fogo. O grupo $\mathrm{G}_{3}$ com média (314.13 e $361.33 \mathrm{~mm}$ ) e mediana (204.50 e 76.00 focos) e o maior DP (196,75 focos) em comparação aos demais grupos. Características ambientais e socioeconômicas são cruciais na dinâmica dos focos de calor no Rio de Janeiro.

PALAVRAS-CHAVE: Incêndios florestais. Queimadas. Satélites ambientais. Métodos estatísticos. Sistemas meteorológicos.

\section{REFERENCES}

ANDERSEN, T.; CARSTENSEN, J.; HERNÁNDEZ-GARCÍA, E.; DUARTE, C. M. Ecological thresholds and regime shifts: approaches to identification. Trends in Ecology \& Evolution, Londres, v. 24, n. 1, p. 49-57, 2009. https://doi.org/10.1016/j.tree.2008.07.014

ANTUNES, M. A. H.; RIBEIRO, J. C. Uso de satélites para detecção de queimada e para avaliação do risco de fogo. Ação Ambiental, Curitiba, v. 2, n. 1, p. 24-27, 2000.

BAILING JÚNIOR, R. C.; MEYER, G. A.; WELLS, S. G. Relation of surface climate and burned area in Yellowstone National Park. Agricultural and Forest Meteorology, Boston, v. 60, n. 3-4, p. 285-293, 1992. https://doi.org/10.1016/0168-1923(92)90043-4

BATISTA, A. C. Mapas de risco: uma alternativa para o planejamento de controle de incêndios florestais. Floresta, Curitiba, v. 30, n. 1, p.45-54, 2003. https://doi.org/10.5380/rf.v30i12.2328

BOSCHETTI, L.; ROY, D.; BARBOSA, P.; BOCA, R.; JUSTICE C. A MODIS assessment of the summer 2007 extent burned in Greece. International Journal of Remote Sensing, Londres, v. 29, n. 8, p. 2433-2436, 2008. https://doi.org/10.1080/01431160701874561

BRITO, T. T.; OLIVEIRA JÚNIOR, J. F.; LYRA, G. B.; GOIS, G.; ZERI, M. Multivariate analysis applied to monthly rainfall over Rio de Janeiro state, Brazil. Meteorology and Atmospheric Physics, Viena, v.129, n. 5, p.469-478, out, 2016. https://link.springer.com/article/10.1007\%2Fs00703-016-0481-X

CAÚLA, R. H. ; OLIVEIRA-JÚNIOR, J. F.; LYRA, G. B.; DELGADO, R. C. ; HEILBRON FILHO, P.F.L. Overview of fire foci causes and locations in Brazil based on meteorological satellite data from 1998 to 2011. Environmental Earth Sciences (Print), Melbourne, v. 74, n. 2, p. 1497-1508, 2015.

https://doi.org/10.1007/s12665-015-4142-z

CAÚLA, R. H.; OLIVEIRA-JÚNIOR, J. F.; GOIS, G.; DELGADO, R. C.; PIMENTEL, L. C. G.; TEODORO, P. E. Nonparametric statistics applied to fire foci obtained by meteorological satellites and their relationship to the MCD12Q1 product in the state of Rio de Janeiro, Southeast - Brazil. Land Degradation \& Development, Londres, v. 28, n. 3, p. 1056-1067, 2016. https://doi.org/10.1002/ldr.2574

CLEMENTE, S. S.; OLIVEIRA JÚNIOR, J. F.; LOUZADA, M. A. P. Focos de Calor na Mata Atlântica do Estado do Rio de Janeiro. Revista Brasileira de Meteorologia, São Paulo, v. 32, n. 4, p. 1-9, 2017. http://dx.doi.org/10.1590/0102-7786324014

CLEMENTE, S. S.; OLIVEIRA JÚNIOR, J. F.; LOUZADA, M. A. P. Focos de calor do bioma Mata Atlântica no estado do Rio de Janeiro: Uma abordagem de gestão e legislação ambiental. Revista de Ciências AgroAmbientais (Online), Alta Floresta, v. 15, n. 1, p. 158-174, 2017. https://doi.org/10.5327/Z1677606220172240

COCHRANE, M. A. Fire science for rainforests. Nature, Reino Unido, v. 421, p. 913-919, 2003. http://dx.doi.org/10.1038/nature01437 
COCHRANE, M. A.; BARBER, C. P. Climate change, human land use and future fires in the Amazon. Global Change Biology, Reino Unido, v. 15, n. 3, p. 601-612, 2009. https://doi.org/10.1111/j.1365-

2486.2008.01786.x

CORREIA, A. H.; FORMAGGIO, A. R.; SHIMABUKURO, Y. E.; DUARTE, V. Avaliação de índices de vegetação MODIS para detecção de desmatamentos na Amazônia. Revista Ambiente e Água, Taubaté, v. 1, n. 2, p.52-64, 2006. https://doi.org/10.4136/ambi-agua.12

COURA, P. H. F.; SOUSA, G. M.; FERNANDES, M. C.; AVELAR, A. S. O uso de variáveis geomorfológicas no estudo da susceptibilidade à ocorrência de incêndios no estado do Rio de Janeiro. Revista de Geografia, Recife, v. 27, n. 2, p. 209-221, 2010.

CPTEC - Centro de Previsão do Tempo e Estudos Climáticos. Monitoramento de focos. Disponível em: $<\mathrm{http}: / /$ pirandira.cptec.inpe.br/queimadas/>. Acesso em: $04 \mathrm{de}$ fev. 2016.

EVERITT, B. S.; DUNN, G. Applied multivariate analysis. Edward Arnold, London, p. 400, 1991. https://doi.org/10.1177/096228029300200109

FERNANDES, M. C.; COURA, P. H. F.; SOUSA, G. M.; AVELAR, A. S. Avaliação Geoecológica de Susceptibilidade à Ocorrência de Incêndios no Estado do Rio de Janeiro, Brasil. Floresta e Ambiente, Seropédica, v. 18, n. 3, p.299-309, 2011. http://dx.doi.org/10.4322/floram.2011.050

GITAS, I. Z.; MITRI, G. H.; VENTURA, G. Object-based image classification for burned area mapping of Creus Cape, Spain, using NOAA-AVHRR imagery. Remote Sensing of Environment, Londres, v. 92, n. 1, p. 409-413, 2004. https://doi.org/10.1016/j.rse.2004.06.006

HUETE, A.; DIDAN, K.; MIURA, T.; RODRIGUEZ, E. P.; GAO, X.; FERREIRA, L. G. Overview of the radiometric and biophysical performance of the MODIS vegetation indices. Remote Sensing of Environment, Londres, v. 83, n.1-2 ,p.195-213, 2002. https://doi.org/10.1016/S0034-4257(02)00096-2

IBGE - INSTITUTO BRASILEIRO DE GEOGRAFIA E ESTATÍSTICA. Área Territorial Oficial e Censo Demográfico Populacional do Brasil. Disponível em:

$<$ http://www.ibge.gov.br/home/geociencias/cartografia/default_territ_area.shtm>. Acesso em: 02 fev. 2018.

KEELEY, J. E.; ZEDLER, P. H. Large high intensity fire events in southern California shrublands: debunking the fine-grained age-patch model. Ecological Applied, Rockville Pike-USA, v. 19, n. 1, p. 69-94, 2009. https://doi.org/10.1890/08-0281.1

LYRA, G. B.; OLIVEIRA-JÚNIOR, J. F.; ZERI, M. Cluster analysis applied to the spatial and temporal variability of monthly rainfall in Alagoas state, Northeast of Brazil. International Journal of Climatology, Londres, v. 34, n. 13, p. 3546-3558, 2014. https://doi.org/10.1002/joc.3926

MACHIWAL, D.; KUMAR, S.; DAYAL, D. Characterizing rainfall of hot arid region by using time-series modeling and sustainability approaches: a case study from Gujarat, India. Theoretical and Applied Climatology, Londres, v. 124, n. 3-4, p. 593-607, 2016. https://doi.org/10.1007/s00704-015-1435-9

MONTGOMERY D. C., RUNGER, G. C. Applied Statistics and Probability for Engineers. $4^{\mathrm{a}}$ Ed., Jonh Wiley \& Sons, Inc., 2007, 490p.

NUNES, M. T. O.; SOUSA, G. M.; TOMZHINSKI, G. W.; OLIVEIRA JÚNIOR, J. F.; FERNANDES, M. C. Variáveis Condicionantes na Susceptibilidade de Queimadas e Incêndios no Parque Nacional do Itatiaia.

Anuário do Instituto de Geociências (UFRJ. Impresso), Rio de Janeiro, v. 38, n. 2, p. 54-62, 2015. https://doi.org/10.11137/2015_1_54_62 
OLIVEIRA-JÚNIOR, J. F.; SOUSA, G. M.; NUNES, M.T.O.; FERNANDES, M. C.; TOMZHINSKI, G. W. Relationship between SPI and ROI in Itatiaia National Park. Floresta e Ambiente, Seropédica, v. 24, p. e20160031, 2017. http://dx.doi.org/10.1590/2179-8087.003116

PIROMAL, R. A. S.; RIVEIRA-LOMBARDI, R. J.; SHIMABURURO, Y. E.; FORMAGGIO, A. R.; KRUG, T. Utilização de dados MODIS para a detecção de queimadas na Amazônia. Revista Acta Amazonica, Manaus, v. 38, n. 1, p. 77 - 84, 2008. http://dx.doi.org/10.1590/S0044-59672008000100009

R CORE TEAM (2017). R: A language and environment for statistical computing. R Foundation for Statistical Computing, Vienna, Austria. URL https://www.R-project.org/.

ROY, D. P.; LEWIS, P.; JUSTICE, C. Burned area mapping using multi-temporal moderate spatial resolution data - a-bi-directional reflectance model-based expectation approach. Remote Sensing of Environment, Londres, v. 83, n. 1-2, p. 263-286, 2002. https://doi.org/10.1016/S0034-4257(02)00077-9

ROY, D. P.; BOSCHETTI, L.; JUSTICE, C. O.; JU, J. The Collection 5 MODIS Burned Area Product - Global Evaluation by Comparison with the MODIS Active Fire Product. Remote Sensing of Environment, Londres, v. 112, n. 9, p. 3690-3707, 2008. https://doi.org/10.1016/j.rse.2008.05.013

SETZER, A. W.; SISMANOGLU, R. A. Risco de Fogo - Resumo do Método de Cálculo (versão 5 - Fevereiro - 2006). Disponível em: <http://pirandira.cptec.inpe.br/queimadas/doc_RF_2007.pdf $>$. Acesso em: 20 de out. 2014.

SETZER, A.W.; VERSTRAETE, M. M. Fire and glint in AVHRR's channel 3: a possible reason for the nonsaturation mystery. International Journal of Remote Sensing, Londres, v.15, n. 3, p. 711-718, 1994. https://doi.org/10.1080/01431169408954111

SILVA, L. S.; LANDAU, L.; MORAES, N. O.; PIMENTEL, L. C. G. Air quality photochemical study over Amazonia Area, Brazil. International Journal of Environment and Pollution, Reino Unido, v. 48, n. 1, p. 194-202, 2012. https://doi.org/10.1504/IJEP.2012.049666

SILVA, T. B.; ROCHA, W.; ANGELO, M. F. Quantificação e análise espacial dos focos de calor no Parque Nacional da Chapada Diamantina - BA. In: XVI Simpósio Brasileiro de Sensoriamento Remoto, 2013, Foz do Iguaçu. Anais... São José dos Campos: Instituto Nacional de Pesquisas Espaciais (INPE), 2013. p. 69696976.

SOBRAL, B. S.; OLIVEIRA JÚNIOR, J. F.; GOIS, G.; TERASSI, P. M. B.; MUNIZ JUNIOR, J. G. R. Variabilidade espaço-temporal e interanual da chuva no estado do Rio de Janeiro. Revista Brasileira de Climatologia, Curitiba, v. 22, n. 1, p. 281-308, 2018. http://dx.doi.org/10.5380/abclima.v22i0.55592

VELÁSQUEZ VALLE, M. A.; MEDINA GARCÍA, G.; COHEN, I. S.; OLESCHKO, L. K.; CORRAL, J. A. R.; KORVIN, G. Spatial Variability of the Hurst Exponent for the Daily Scale Rainfall Series in the State of Zacatecas, Mexico. Journal of Applied Meteorology and Climatology, Boston, v. 52, n. 1, p.2771-2780, 2013. https://doi.org/10.1175/JAMC-D-13-0136.1

WARD, J. H. Hierarchical grouping to optimize an objective function. Journal of the American Statistical Association, Minnesota-USA, v. 58, n.1, p. 236-244, 1963. https://doi.org/10.1080/01621459.1963.10500845. 